\title{
HOW TO IMPROVE SOFT SKILLS OF ACCOUNTING STUDENTS
}

\author{
DOI: 10.17261/Pressacademia.2020.1248 \\ PAP- V.11-2020(20)-p.98-100
}

\section{Sinem Ates \\ Yalova University, Department of Business Administration, Yalova, Turkey.} sinem.ates@yalova.edu.tr, ORCID: 0000-0002-9999-3799

\section{To cite this document}

Ates, S., (2020). How to improve soft skills of accounting students. PressAcademia Procedia (PAP), V.11, p.98-100

Permanent link to this document: http://doi.org/10.17261/Pressacademia.2020.1248

Copyright: Published by PressAcademia and limited licensed re-use rights only.

\begin{abstract}
Purpose- The purpose of this study is to highlight the views and suggestions of undergraduate students regarding the need for and alternative ways of integration of soft skills into the accounting curriculum.

Methodology- The answers to open-ended questions in a self-reporting questionnaire conducted to the final year students in the department of business administration were analysed through a descriptive phenomenological approach.

Findings- The main results reveal that most of the students who attend this research think that the accounting curriculum should not cover only technical issues but also include some extra modules to improve the soft skills (critical thinking, verbal communication, written communication, interpersonal skills, team-working, time management, stress management, listening and so on) of accounting students. The most preferred method of improving the soft skills of accounting students is determined as a stand-alone "Project Module" which involves working with the professionals at the relevant organizations. They think that, besides encouraging the development of soft skills, such a Project Module would provide permanent technical information and a chance to see whether the student is interested in the accounting profession.

Conclusion- Based on the findings it can be concluded that accounting students are aware of the employers' requirement of soft skills and expect to gain these soft skills during their graduate education. The findings of this study should prompt the academic community and the accounting curriculum should be revised to be aligned with the expectations of accounting students and employers.
\end{abstract}

Keywords: accounting curriculum, soft skills, accounting education, technical information, social skills JEL Codes: M41, 123, A22

\section{INTRODUCTION}

For several decades, accounting degrees have been criticized for their overly technical teaching and inability to improve non-technical skills (Jackling \& Lange, 2009; Douglas \& Gammie, 2019). Not only employers but also professional accounting bodies emphasize the necessity of the development of soft skills (IFAC, 2010; The Pathways Commission, 2012...) through accounting education. Along with the fact that the role of the accountant has evolved from a technical expert to an advisor recently (Hiller et al., 2014), soft skills has gained much more importance. The pressure on the academy to improve the soft skills of accounting students besides their technical capabilities makes it critical to investigate and suggest effective ways for the achievement of this challenging task. From this point of view, the purpose of this study is to highlight the views of undergraduate students regarding the need for the integration of soft skills into the accounting curriculum. This study also aims to highlight suggestions of undergraduate students regarding alternative ways of integration of soft skills into the accounting curriculum. To this end, a questionnaire including open-ended questions was conducted to a sample of 22 final year students in the department of business administration. Analysis of answers to these open-ended questions through a phenomenological approach shows that most of the undergraduate students think that the accounting curriculum should not cover only technical issues but also include some extra modules to improve the soft skills of accounting students. Among several alternatives, a stand-alone "Project Module" which involves working with the professionals at the relevant organizations is determined as the most preferred method by undergraduate students. They also suggest in-class discussions, team games, computer-based training, inviting an accounting professional to the class to help students improve their soft skills. The results of this study are informative for both employers and the academic community.

\section{LITERATURE REVIEW}

Soft skills, generic skills, non-technical skills are often used interchangeably in the literature. Boyce et al. (2001, p. 37) define soft skills as "the range of general education skills that are not domain-or practice-specific, which include communication and interpersonal skills, problem-solving skills, conceptual/analytical and critical skills, visual, oral and aural skills, and judgement and synthesis skills". 
The importance of soft skills has been mainly attributed to the globalization, marketplace complexity, technological advancements, changing expectations of employers, students, and accreditation authorities by de Villiers (2010). It was found that $75 \%$ of job success is dependent on soft skills (Klaus, 2010). Employers are known to value soft skills more than technical skills (Adecco Group, 2013).

Due to the increasing importance of soft skills, some professional organizations develop several frameworks to prompt the integration of soft skills into the accounting curriculum. The AICPA Pre-certification Core Competency Framework by the American Institute of Certified Public Accountants' (AICPA, 1999), International Education Standard (IES) 3 issued by International Federation of Accountants (IFAC, 2003), Accreditation Standards of the American Association to Advance Collegiate Schools of Business are just a few of examples for these frameworks.

While there has been a call from employers and professional organizations to integrate soft skills into the accounting curriculum some of the academic community does not agree with the rationality of this attempt. They claim that it is not realistic to expect accounting education at the undergraduate level to satisfy the demands regarding the development of soft skills. The proponents of this view argue that class time is limited and would not be enough to teach both technical issues and soft skills at the same time. They also question whether accounting professors have the knowledge and expertise to achieve the challenging task of improving the soft skills of students? They also attract attention to the increasing demand to integrate data analytics into the accounting curriculum and thereby improve the technological capabilities of students. Finally, based on these arguments, they claim that it is impossible to meet all of these demands, thereby, suggest that the issues which can be covered by the accounting curriculum and which must be left to "on the job" training should be specified (Rebele and Pierre, 2019).

Based on these two opposing views in the literature, it would be meaningful to ask this question: Is it possible to integrate soft skills into the accounting curriculum without compromising the technical competence of the students? Actually, there are some suggestions on this issue, one of which belongs to Byrne and Lees (2018). They suggest a stand-alone project module as a curriculum-space saving solution to help students develop their soft skills. This module involves working with the professionals at the relevant organizations on a specific issue and then writing a project about this experience. Based on the paper of Byrne and Lees (2018), this study aims to determine whether undergraduate students think that a stand-alone project module would be useful to improve their soft skills.

\section{DATA AND METHODOLOGY}

In this study, a questionnaire including open-ended questions was conducted to a sample of 22 final year students in the department of business administration. The questionnaire was developed based on the paper of Byrne and Lees (2018) who suggested a stand-alone project module as a curriculum-space saving solution to help students develop their soft skills.

Students were mainly asked to explain;

- their opinions regarding the necessity of integration of soft skills (verbal communication, written communication, interpersonal skills, team-working, time management, stress management, listening...) into the accounting curriculum

- their preference for the ways to improve the soft skills of accounting students

- $\quad$ a real project which they would like to conduct

- $\quad$ their suggestions to improve the soft skills of accounting students

A descriptive phenomenological approach was used to analyze the answers of undergraduate students to the open-ended questions in the mentioned questionnaire. The descriptive phenomenological approach is useful when the aim is to explain and understand the phenomenon from the viewpoint of those directly concerned (Speziale et al., 2011).

\section{FINDINGS}

Analysis of the undergraduate students' answers reveals that they are aware of the importance of soft skills in business life.

...Students should also be developed socially so that they can adapt to business life and do their job more easily (Student-5).

...Trying to learn "critical thinking, stress \& time management, teamwork, written, and oral communication during business life will be difficult. It can adversely affect our motivation, our belief in ourselves, and our success (Student-8).

Most of the students think that the accounting curriculum should not cover only technical issues but also include some extra modules to improve the soft skills of accounting students. Only 2 of 22 students argue for the opposite.

I think it should only cover technical issues. Because technical issues are already difficult to understand, and they (accounting graduates) will generally not need social skills in business life. But a few of these skills are of course useful. For example, oral communication... They will always be in communication with someone throughout their business life (Student-12).

... I think technical information should be predominant for the accounting students.... (Student-14).

They mostly prefer a stand-alone "Project Module" to improve their soft skills during undergraduate education. They think that, besides encouraging the development of soft skills, such a Project Module would provide permanent technical information and a chance to see whether the student is interested in the accounting profession.

.... Another benefit is that he/she realizes whether he/she is really interested in accounting and he/she can draw the career path more clearly...(Student-3). 
Finally, they suggest in-class discussions, team games, computer-based training, inviting an accounting professional to the class to help students improve their soft skills.

\section{CONCLUSION}

In line with the purpose of identifying the views and suggestions of undergraduate students regarding the need for and alternative ways of integration of soft skills into the accounting curriculum, a questionnaire including open-ended questions was conducted to 22 final year students in the department of business administration.

The main results of the study suggest that undergraduate accounting students are aware of the employers' requirement of soft skills. They expect to gain these soft skills during their graduate education, not on the job. Based on these findings it is possible to argue that the accounting curriculum should be revised to be aligned with the expectations of accounting students and employers. However, the needs, suggestions, and criticisms of the academic community should also be taken into consideration while planning this change in the accounting curriculum.

Further research might explore the views of accounting academicians regarding alternative ways of improving the soft skills of accounting students. A comparison between the expectations of academicians and students would be useful to achieve common objectives for developing the soft skills of accounting students.

\section{REFERENCES}

Adecco Group North America. (2013) The Skills Gap and the State of the Economy, Retrieved May 13, 2020, from http://blog.adeccousa.com/the-skills-gap-and-the-state-of-the-economy.

American Institute of Certified Public Accountants (AICPA). 1999. The AICPA Pre-certification Core Competency Framework, Retrieved May 13, 2020, from https://www.aicpa.org/content/dam/aicpa/interestareas/accountingeducation/resources/downloadabled ocuments/aicpa pre-certification-core-compentency-framework.pdf.

Boyce, G., Williams, S., Kelly, A., Yee, H. (2001). Fostering deep and elaborative learning and generic (soft) skill development: the strategic use of case studies in accounting education. Accounting Education, 10(1): 37-60.

Byrne, D., Lees, D. (2018). Finance and Accounting-Beyond the Numbers with Self-Leadership. E. Conway, D. Byrne (Eds.), Contemporary Issues in Accounting (pp. 15-35). Cham, Switzerland: Palgrave Macmillan.

De Villiers, R. (2010). The incorporation of soft skills into accounting curricula: preparing accounting graduates for their unpredictable futures. Meditari: Research Journal of the School of Accounting Sciences, 18(2): 1-22.

Douglas, S., Gammie, E. (2019). An investigation into the development of non-technical skills by undergraduate accounting programmes. Accounting Education, 28(3): 304-332.

Hiller, K., Mahlendorf, M. D., \& Weber, J. (2014). Management accountants' occupational prestige within the company: A social identity theory perspective. European Accounting Review, 23(4): 671-691.

International Federation of Accountants (IFAC). (2003). International Education Standard 3, Initial Professional Development - Professional Skills (Revised). IFAC: New York. Retrieved May 12, 2020, from https://www.ifac.org/system/files/publications/files/IAESB-IES-3Professional-skills.pdf.

International Federation of Accountants. (2010). Handbook of international education pronouncements. Retrieved May 18, 2020, from http://www.ifac.org/publications-resources/handbook-international-education-pron ounceme nts-2010-edition.

Jackling, B., De Lange, P. (2009). Do accounting graduates' skills meet the expectations of employers? A matter of convergence or divergenc. Accounting Education: An International Journal, 18(4-5): 369-385.

Klaus, P. (2010). Communication breakdown. California Job Journal, 28: 1-9.

Pathways Commission. (2012). Charting a national strategy for the next generation of accountants. Sarasota, FL and New York, NY: American Accounting Association and American Institute of CPAs Retrieved May 18, 2020, from http://commons.aaahq.org/files/0b14318188/Pathways Commission Final Report Complete.pdf.

Rebele, J. E., Pierre, E. K. S. (2019). A commentary on learning objectives for accounting education programs: The importance of soft skills and technical knowledge. Journal of Accounting Education, 48: 71-79.

Speziale, H. S., Streubert, H. J., Carpenter, D. R. (2011). Qualitative research in nursing: Advancing the humanistic imperative. Lippincott Williams \& Wilkins. 